\title{
Young South Africans and cultural (mal)practice: Breaking the silence in recent writing
}

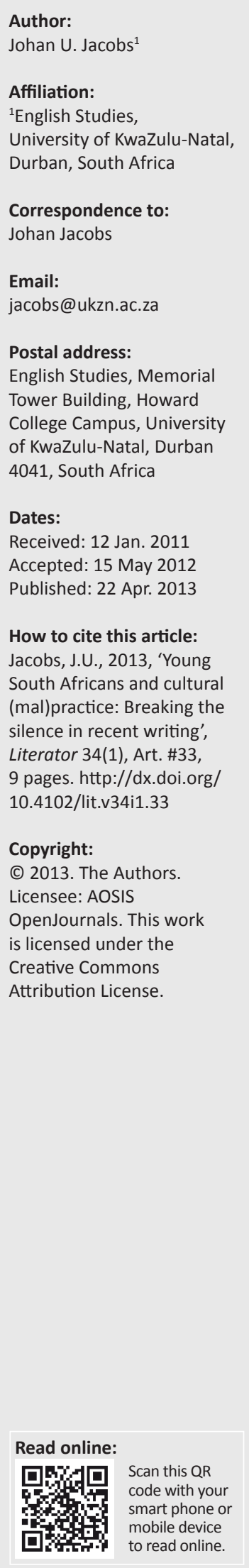

This article considered the literary representation of young South Africans coming of age within a post-apartheid, multicultural context and forging for themselves a modern identity across a divide between, and also within, cultures. They identify themselves with the global West, but also subscribe to indigenous African values, whilst recognising how they themselves have been damaged by corrupted cultural practices. Postcolonial theories of identity-formation - Said's argument that post-imperial cultures are all hybrid and heterogeneous, Bhabha's interstitial 'third space' where postcolonial identities are produced through processes of negotiation and translation, Hall's theory that cultural identity is based on differences and discontinuities rather than on fixed essences, De Kock's notion of a 'cultural seam' or site where cultures both differ and converge and difference and sameness are sutured together, Nuttall's notion of entanglement, and Clingman's theory of the transitive self - are used for understanding how young South Africans are shown in recent writing as having been shaped by traditional cultural practices and also damaged by cultural malpractices. Texts chosen for discussion are Adam Ashforth's Madumo, about witchcraft, Russell Kaschula's short story, 'Six teaspoons of sweetness' and Gcina Mhlope's short story, 'Nokulunga's wedding', both of which deal with $u$ kuthwala [forced marriage abduction] and, finally, Thando Mgqolozana's novel, A man who is not a man, which deals with the consequences of a botched traditional circumcision. The article argued that self-reflexive critical and imaginative engagement by young people with the cultures that have formed - and deformed - them is a mark of the true coming-of-age of postcolonial and post-apartheid writing.

Jong Suid-Afrikaners en kulturele (wan)praktyke: Verbreking van die stilte in onlangse prosa. Hierdie artikel ontleed die uitbeelding van jong Suid-Afrikaners wat in 'n multikulturele konteks tot volwassenheid kom en vir hulself 'n moderne identiteit bou oor die klowe tussen - en binne - verskillende kulturele stelsels. Enersyds vereenselwig hulle hul met die globale Weste, en andersyds behoort hulle tot inheemse Afrika-kulture. Tegelykertyd besef hulle hoe hul geskaad is deur verworde kulturele gebruike. Postkoloniale teorieë oor identiteitsvorming - Said se siening van postimperialistiese kulture as hibried en heterogeen, Bhabha se 'derde ruimte' waar postkoloniale identiteite gevorm word deur onderhandeling en vertaling, Hall se teorie dat kulturele identiteit gebaseer is op verskille en diskontinuiteite eerder as op enersheid, De Kock se beeld van ' $n$ 'kulturele naat' waar wydlopende kulture saamkom en verskille en ooreenkomste 'saamgestik' word, Nuttall se siening van kulturele verstrengeling en Clingman se siening van 'n oorganklike sintaksis van die self - word gebruik om te onthul hoe die vorming asook skending van jong Suid-Afrikaners deur inheemse kulturele instellings voorgestel word in hedendaagse prosa. As voorbeelde dien Adam Ashforth se boek, Madumo, oor geloof in toordery, Russell Kaschula en Gcina Mhlope se kortverhale, 'Six teaspoons of sweetness' en 'Nokulunga's wedding', wat handel oor ukuthwala [Xhosa vroueroof] en Thando Mgqolozana se roman, A man who is not a man, oor die nagevolge van 'n verknoeide tradisionele besnyding. Die artikel voer aan dat verbeeldingryke selfrefleksie deur jongmense oor die kulture waardeur hulle gevorm - en misvorm - is, ' $n$ blyk van die volwassewording van 'n postkoloniale en postapartheid letterkunde is.

\section{Introduction}

\section{The multicultural South African context}

An important part of the postcolonial project - and in the case of South Africa, the postapartheid project - is to recover precolonial and pre-apartheid cultural traditions and practices and to promote indigenous knowledge systems. Chapter One, Section 6.1 of the South African Constitution (Republic of South Africa 1996:1) specifies, amongst its founding provisions, the eleven official languages of the country - Sepedi, Sesotho, Setswana, siSwati, Tshivenda, Xitsonga, Afrikaans, English, isiNdebele, isiXhosa and isiZulu - and recognises, in Section 6.2, the need to elevate the status and advance the use of the indigenous languages, including the Khoi, 
Nama and San languages and, by implication, their cultural systems and epistemologies. ${ }^{1}$ Chapter Two, the Bill of Rights, guarantees, in Section 15.1 (1996:3), 'the right to freedom of conscience, religion, thought, belief and opinion', whilst Sections 30 and 31 (1996:7) provide for everyone's right 'to use the language and to participate in the cultural life of their choice', together with other members of their community.

Within this multicultural and multilingual constitutional framework, the National House of Traditional Leaders Act (Act No. 22 of 2009) (Republic of South Africa 2009) creates a space in the governance structures of the modern democratic state for the rulers of traditional communities and their councils. Alongside Western biomedicine, the Traditional Health Practitioners Act (Act No. 22 of 2007; Republic of South Africa 2008) legalises and regulates the work of thousands of traditional healers and surgeons, providing it is based on 'traditional philosophy', which:

means indigenous African techniques, principles, theories, ideologies, beliefs, opinions and customs and uses of traditional medicines communicated from ancestors to descendants or from generations to generations, with or without written documentation, whether supported by science or not, and which are generally used in traditional health practice. (Republic of South Africa 2008:ch 1.1, ln 51-55)

In South Africa, customary law is recognised together with state law and allows polygamy - the most prominent polygamist being President Jacob Zuma, who currently has four wives and acknowledges some twenty-odd children from various relationships. Zuma's adherence to what many South Africans regard as an archaic, patriarchal Zulu cultural tradition in conjunction with his position as leader of a modern, sophisticated democracy has been controversial. The most notorious polygamist in southern Africa is surely the corrupt King Mswati III of Swaziland, Africa's last absolute monarch who, with his 13 wives - each having her own palace - and 27 children, his appetite for Western luxuries and his personal fortune of US\$100 million, has bankrupted his small country, whose citizens - many of whom have been diagnosed with HIV and/or AIDS - are denied basic civil rights. ${ }^{2}$

\section{Traditional customs and their abuse}

Various indigenous cultural practices have either survived or been reinvented in contemporary South Africa. Gerhard Stilz (2009) explains why the continuation of traditional cultural ceremonies is important for an understanding of indigenous identity:

Local customs and festivals are usually thought to be impressive and efficient demonstrations of indigenous identity. There is indeed something to be said in favour of their longevity, exactly because they are well-proven ways of gracing and making

1.See Mumia Geoffrey Osaaji's (2009:125) discussion of language and culture with reference to endangered languages: 'Language, which is the embodiment of the unique cultural wisdom of a people, is the most efficient means of transmitting a culture ... A language engenders the roots, philosophy, culture, heritage and communication of a people'.

2.Mswati 'clings to antiquated traditions that promote rampant promiscuity in a land ripped apart by Aids, where elderly princes take child brides under the cloak of culture, corruption is rife and fawning courtiers feud for favours as their country falls apart. Swaziland has the world's highest HIV rates and lowest life expectancy. Th economy is collapsing so fast even pensions have been stopped' (Birrell 2011:15). bearable the sombre cutting edges between life and death. A special birth rite, an initiation procedure, a wedding ceremony, a funeral, all placed at those incisive thresholds of life that beg for meaning, may reveal much about the particular world view of a community. (Stilz 2009:23-24)

The collection of essays in the volume, Zulu identities: Being Zulu, past and present, edited by Benedict Carton, John Laband and Jabulani Sithole (2008), for example, provides valuable insights into traditional as well as contemporary aspects of 'Zuluness'. The old Zulu custom of ilobolo ${ }^{3}$ [bridewealth], whereby a man is required to pay his prospective wife's family a number of cattle, still continues, although these days payment is often made in cash. The Zulu umemulo, or ukuthomba [coming-of-age ceremony], is still held to celebrate a girl's 'blossoming forth' into womanhood, 'which requires ritual notification of and permission from the amadlozi [ancestors]' (Magwaza 2008:482). In September 2011, 30000 Zulu maidens once again took part in the annual Reed Dance (uMkhosi woMhlanga) and each presented a reed as a symbol of their purity to the Zulu King Goodwill Zwelithini at his palace in Nongoma.

More questionably, however, ukuhlolwa kwezintombi [virginity testing] has been revived in KwaZulu-Natal. According to Tessa Marcus (2008:536), these public virginity testing ceremonies, with their crude physical inspections and subsequent certification of the graduates, have been reinvented by older isiZulu-speaking women 'to strengthen controls over assertive youthful behaviour and reverse some of the devastating causes of domestic breakdown' as a result of the HIV and AIDS pandemic. Even more dubious was the invention in KwaZulu-Natal in 1996 of a threeday ritual in honour of Nomkhubulwane, the Zulu fertility goddess, with its male and female izangoma [diviners] in procession, chanting and drum-beating, sacrifice and burnt offering of a goat and chickens, virginity testing, frenzied traditional dancing, and eventual naked bathing of the graduates in the nearest river - all this allegedly to reaffirm Zulu identity, restore a lost culture, recover 'traditional moral values and sexual practices' (Lambert 2008:546), fight gender discrimination and racism, combat the spread of AIDS, and generally enhance the African spirit of $u b u n t u$, or common humanity, in a mish-mash of what Michael Lambert (2008:551) calls 'Africanist romanticism, supported by current political rhetoric about the African Renaissance, indigenous knowledge systems and Western feminism'.

\section{Cross-cultural identities}

Edward Said's (1994:xxix) argument that all post-imperial cultures are involved in one another; 'none is single and pure, all are hybrid, heterogeneous, extraordinarily differentiated, and unmonolithic' holds true for South Africa today. Speaking of the hybridities that emerge in times of historical transformation, Homi Bhabha (1994) has argued that postcolonial cultural identities are formed in the interstices, or liminal spaces, between cultural systems. In these 'inbetween' spaces, which Bhabha calls the 'Third Space' (see 3.See W.D. Hammond-Tooke's (2008) explanation of ilobolo in the context of the symbolic value of cattle in Zulu culture. 
Bhabha 1994:36-39), 'complex figures of difference and identity, past and present, inside and outside, inclusion and exclusion' (Bhabha 1994:1) are produced through processes of negotiation and translation. These 'borderline engagements of cultural difference', he says, whether consensual or conflictual, 'may confound our definitions of tradition and modernity; realign the customary boundaries between the private and the public, high and low; and challenge normative expectations of development and progress' (Bhabha 1994:2).

Many young South Africans inhabit these contradictory 'inbetween' cultural spaces where they have to negotiate their identities in different ways. According to recent estimates, $51 \%$ of South Africa's population of 50 million people are under the age of $24 ; 20 \%$ are between the ages of 15 and 24. Of the latter, $51 \%$ are unemployed and nearly $10 \%$ are HIV-positive (Statistics South Africa 2011:3-8). This article will examine the ways in which, in four contemporary texts - one sociological and three fictional - young South Africans are depicted as attempting to forge a modern identity for themselves across a divide between, and also within, cultures. On the one side, they identify themselves with the global West; on the other side, they also subscribe to traditional African value systems; but they recognise, too, how they have been damaged by cultural practices that have become corrupted. These writings are beginning to break the silence around malpractice in the name of cultural tradition in South Africa today.

\section{Witchcraft and Westernism: Adam Ashforth's Madumo}

In Madumo: A man bewitched, the Australian-born social scientist Adam Ashforth (2000), who has, since 1990, spent periods living in Soweto whilst doing research on the South African transition to democracy, presents a picture of his friend, the eponymous Madumo. Madumo is the kind of hybrid text that, according to Said, reflects the hybridity of the postcolonial and post-imperial world: not only does Ashforth offer a qualitative sociological study of witchcraft in present-day Soweto, but the figure of his protagonist is also representative of the young Black South African in the interspace between conflicting modern and indigenous cultural systems.

On his last return visit to Soweto, Ashforth finds Madumo destitute and depressed as a result of having been thrown out by his brother and his family who accuse him of causing the premature death of their mother through witchcraft. Ashforth (2000:17) says that amongst Black South Africans in Soweto, witchcraft lurks under the surface of everyday life and is part of a general spiritual insecurity which 'cannot be divorced from the religious, cultural and political history of the place and its people'. The presence of witches and their familiars - cats, baboons, snakes - is widely accepted and it is usually the vulnerable members of society - old women and the mentally disturbed - who fall victim to accusations of being witches. Witchcraft is often used out of sexual jealousy or material envy and represents the dark opposite of the spirit of ubuntu. And the darkest aspect of witchcraft in South Africa today is the frequency of so-called muthi murders: the killing of (usually) young children for the use of their body parts by witchdoctors to make powerful medicine. Although Ashforth declares that he himself has doubts about how widespread this practice actually is, he acknowledges the frequency with which muthi killings are reported in the South African media:

I've heard countless stories over the years about these so-called muthi murders, the killing of people for body parts to use in magic medicines. Most of these I tend to discount as urban legends, although periodically the local press will carry reports of court cases involving the procurement and sale of human body parts or else report the discovery of mutilated corpses. (Ashforth 2000:124)

In his capacity as sociologist, Ashforth - himself a religious sceptic - details many of the beliefs shared by Black South Africans: in the tokoloshe, a hairy little creature with enormous genitals and a voracious sexual appetite, who preys mostly on women; in Inkosi ya Manzi, the King of the Water, who threatens those shack dwellers erecting their shacks too close to the river where he lives; in Inyoni Yezulu, the lightning bird of the heavens that lays its eggs when it strikes; and in the isidliso, which is sent to the victim by a witch through adulterated food or drink, and 'which takes the form of a small creature lodged in the gullet' (Ashforth 2000:167), a crab or a frog or even a lizard, that:

slowly consumes its victim, creating all manner of hardship and pain along the way, such as friendships breaking, lovers leaving, or jobs disappearing ... Once inside its victim, the isidliso is in a battle to the death and the victim must engage a powerful healer to repel it. (Ashforth 2000:167)

In the role of researcher as participant-observer, Ashforth records the stages of Madumo's treatment by the inyanga [healer], Mr Zondi. These include, amongst others, (1) Zondi's burning mphepho herbs in a dish for the ancestors to speak to him through the smoke, and pricking Madumo's entire body with porcupine quills to chase away the evil spirits; (2) Madumo's steaming himself over boiled roots and drinking a herbal concoction for two weeks to induce non-stop vomiting and so purge himself; (3) being bathed in a mixture of chicken gall, herbs and soil from his mother's grave; (4) having his body smeared with sap from a tree; (5) having small incisions made on his temples, neck, elbows, wrists, knees and ankles, and a special mixture of herbs blended with mercury rubbed into them and (6) holding a feast for his ancestors with a slaughtered ram and freshly brewed beer at his uncle's homestead. During this process, Madumo also subjects himself to the purification rituals of the prophets of the Zion Christian Church, through whom the spirits of the ancestors similarly speak.

4.See, for example, the following newspaper reports of muthi (both spellings are used) killings among the many that have appeared during the past year alone: 'Muti used) killowo house of horror' (Daily News 04 February 2011:3), 'Three held after man killed for body parts' (Sunday Tribune 06 February 2011:4), 'Mutilated body indicates muti killing' (The Mercury 02 August 2011:4) and 'Relatives cheer as muti killer is jailed' (The Mercury 29 November 2011:5). For a discussion of the legal aspect of muthi murders see Anthony Minnaar's (2003:33-92) essay, 'Legislative and legal challenges to combating witch purging and muti murder in South Africa'. 
When Madumo has emerged apparently cured, Ashforth (2000:253) asks the larger, more imaginative question that a writer of fiction might also pose: how can an intelligent, westernised young man, a university student, whose life is 'mostly lived on the same sorts of terms as anywhere', also actively believe in the whole business of witchcraft? Ashforth realises that, for Madumo, it is not a matter of either believing or not believing, but rather one of both believing in the work of witches and being western. In Madumo's own words: "Most of the time I try to Westernize my mind and not think about witchcraft"' (Ashforth 2000:246). Ashforth (2000:247) says that for Madumo, "'Westernizing the mind" is not a way of denying the reality of witchcraft but a mode of combating the real powers of witches'. Madumo's identity is negotiated on a daily basis in terms of two conflicting paradigms. His experience gives special substance to Stuart Hall's (1990:225) often-cited argument that cultural identity is based on differences and discontinuities rather than on fixed essences, and that it is 'a matter of "becoming" as well as of "being"'. Cultural identities, Hall (1990:226) says, are 'the unstable points of identification or suture, which are made, within the discourses of history and culture. Not an essence, but a positioning ...'.

The figure of the young South African Madumo exemplifies the kind of identity that Stephen Clingman (2009:16, 21) defines as being based on a syntax of the self which, he says, in 'its combinatory, unfolding possibilities ... is a transitive syntax': on the basis of recursion and combination, it navigates across boundaries, linking 'syntax within the self to syntax beyond the self'. Such an identity recognises boundaries that demarcate differences, but is also transitive in its engagement with and crossing of those boundaries. The transitive imagination, Clingman (2009:21) says, is premised on the paradoxical interdependence of navigation and the boundary - as he expresses it: 'navigation occurs not despite but because of the boundary'. A transitive syntax of the self 'does not override or negate difference within the self or in relation to others - indeed ... it depends on it. But it does hold out the possibility of connection' (Clingman 2009:15). According to Clingman (2009), it is precisely this capacity for navigation across boundaries that provides the self with its transitive form:

Differences within the self or between the self and other selves are not overridden or transcended ... Rather, they become the foundation of identity as a kind of meaning - but meaning considered always as navigation, exploration, transition. (p. 22)

Madumo emerges from Ashforth's text as a persona whose transitivity is akin to that of the fictional characters in the narratives that follow.

\section{Ukuthwala: Customary marriage abduction and womanhood}

The further question arises of how young people position themselves in relation to cultural traditions that have become corrupted Or, as Bulelwa Nosilela (2010:2) asks, for example: how does a woman, who identifies herself as a Xhosa by virtue of the 'language, traditions, behaviours, perceptions and beliefs' that she shares with other Xhosas, deal with cultural practices that are, as she expresses it, no longer the ones handed down by her ancestors? Ukuthwala, an age-old amaXhosa marriage custom, is one such instance. In the past, once the union had been negotiated between the two families and the lobola agreed upon, the unsuspecting girl was ambushed and abducted, according to plan, by her prospective husband and his friends. She was then forcibly taken to the young man's homestead, where she would be awaited by his kinswomen, calmed down and welcomed before being taken to the young man's hut.

These days a debased form of ukuthwala is rife in the Eastern Cape, with schoolgirls as young as 12 being kidnapped by older, often HIV-infected men, raped, kept captive as wives, and lobolo paid to their families in compensation for the child. Nomboniso Gasa (2010:3), a researcher on gender and culture, warns against the indiscriminate romanticising of traditional cultural practices. She distinguishes between, on the one hand, 'ukugcagca (elopement), ukuziba (when a young couple steal for themselves the right to marry to force the hand of the elders), and ukuzekelwa (to be forced into an arranged marriage)' and on the other hand, ukuthwala, which she says is neither a sacred rite nor a custom, but one of the dark corners of traditional culture, and simply 'a modus operandi of taking girls often without their knowledge or even consent into marriage'. Speaking about the South African report in 2009 to the international Convention on the Elimination of all Forms of Discrimination against Women, a cabinet minister, Doctor Manto Tshabalala-Msimang (2009:4), identified abduction, forced and early marriage as harmful traditional practices, the result of patriarchal attitudes persisting in South African society, and manifesting themselves in 'negative and harmful ways against women and girls'. In 2009, she held an imbizo [conference] in the Eastern Cape with traditional leaders, political leaders, school teachers, school children and young people on how to address and prevent the practice of ukuthwala. On 29 August 2011, the National Prosecuting Authority published a newspaper feature on 'Waging war against [the] criminal element of ukuthwala practice', identifying it as a crime in terms of the Constitution, the Sexual Offences and Related Matters Act (Act No. 32 of 2007) (Republic of South Africa 2007) and the Children's Act (Act No. 38 of 2005) (Republic of South Africa 2005) and detailing some successful convictions and sentences meted out to abductors. Ukuthwala has also been the subject of a number of documentary films in 2011, including an episode in a television documentarydrama programme, The Final Verdict, co-produced by the Department of Justice and Constitutional Development and the South African Broadcasting Corporation (SABC), an investigative documentary, Ukuthwala, shown on the SABC Special Assignment programme in February, as well as the documentary, Ukuthwala - Stolen Innocence, which was launched early in the year by the World Aids Campaign. There was even a musical, uQongqothwane (The Musical), about $u$ kuthwala, which was performed at the Port Elizabeth Opera House in August. 


\section{Russell Kaschula's 'Six teaspoons of sweetness'}

Russell Kaschula's (2011) short story, 'Six teaspoons of sweetness', is described by Tim Huisamen (2010:23) as both a 'portrait of the woman as a young girl' and 'a coming of age story'. The protagonist, the 15-year-old Sweetness, who lives in a village between Port St Johns and Lusikisiki in the Eastern Cape, is depicted as a young person caught in a cultural double-bind in a patriarchal society. As firstperson narrator and focaliser, she registers, but does not comprehend the implications of the negotiations between the party of older men who come to visit her father and brother; she remains mute, as she says, 'one who does not speak, who is not spoken to' (Kaschula 2011:209). The debate, however, is about her, 'by men, for men'.

To appreciate the complexity of both the cultural situation and the fictional narrative, one might turn to Sarah Nuttall's (2009) notion of entanglement, which she proposes as a way of getting beyond the binary lenses of colonialism and apartheid and responding to the challenge of the postapartheid present. According to Nuttall (2009) (echoing Said's thesis about the hybridity of post-imperial cultures):

Entanglement is a condition of being twisted together or entwined, involved with; it speaks of an intimacy gained, even if it was resisted, or ignored or uninvited. It is a term which may gesture towards a relationship or set of social relationships that is complicated, ensnaring, in a tangle, but which also implies human foldedness. It works with difference and sameness but also with their limits, their predicaments, their moments of complication. (p. 1)

Nuttall (2009) further suggests that entanglement:

is a means by which to draw into our analyses those sites in which what was once thought of as separate - identities, spaces, histories - come together or find points of intersection in unexpected ways. It is an idea which signals largely unexplored terrains of mutuality, wrought from a common, though often coercive and confrontational experience. (Nuttall 2009:11)

Sweetness epitomises cultural entanglement. She is rooted in traditional Xhosa culture: she does not question male authority, she believes in the presence of the ancestral spirits just as she fears the half-fish, half-cow river monster with one eye that preys on children, and she proudly undergoes the intonjane initiation rite together with other young girls, having their faces painted with white clay, being secluded, participating in their first bare-breasted menstruation dance, and being instructed in the values and responsibilities of womanhood by their elders. However, she also believes in the value of modern education, which is symbolised by the set of pens given to her as a coming-of-age present by her teacher. Sweetness says of the red ochre beads with which they are decorated: They 'speak of who I was, who I am' (Kaschula 2011:212).

The narrative mode is similarly hybrid, or entangled. The reader is drawn into the immediate drama of the unfolding events by the focalisation of the young girl and her presenttense narration. When she is captured by a group of young men whilst collecting firewood in the forest, she immediately realises what has happened to her: 'Ukuthwalwa [sic] customary marriage abduction - that is it. It is now a matter of cows, dowry - negotiations' (Kaschula 2011:213). When she is taken to the homestead of her husband-to-be on the outskirts of Lusikisiki, she has no choice but to submit to the short, fat man 'with bad brandy breath' (p. 214) who, is old enough to be her father. She flees from him in the early hours of the morning, but, to her dismay, is returned by her father and told to behave like a married woman because the 'custom is sacred' (p. 216). For a week she observes all the customs and taboos of a newly married umakoti - wearing a long shweshwe marriage dress and covering her head with a black qhiya-doek, being denied anything sweet, never looking her husband in the eyes and keeping his name and even the sounds of his name from her lips (ukuhlonipha).

The narrative realism is accompanied, however, by a traditional African epistemology, which adds a more complex, richer dimension to the storytelling. When Sweetness flees again, and stays away for nine years, she identifies herself with the forest and with the white owl in flight from a falcon. She conceptualises herself as being protected by a covering of white ochre and as having found refuge in 'the safety of the ochre spirit-world' (Kaschula 2011:218), unseen and voiceless - although in reality, with the help of her teacher, she finishes her schooling in a distant village and eventually qualifies as a teacher. As she says in conclusion, in a complex statement of her identity as a young, modern Xhosa woman when she visits her father's homestead again: 'man, woman, forest and spirit, all one' (p. 219), she cannot deny her ancestral home although it has betrayed her.

\section{Gcina Mhlophe's 'Nokulunga's wedding'}

The short story, 'Nokulunga's wedding', from the collection Love child (2002), by the playwright and storyteller-performer, Gcina Mhlophe, displays many of the characteristics of a performance piece: short sentences for dramatic effect; rhythmic progression through a series of mini-climaxes within the narrative; deliberate pauses to heighten the tension, a narrative dynamic maintained through the combined use of a third-person narrator and the figure of the 16-year-old Nokulunga as internal focaliser; strategic punctuation of the narrative with bits of dialogue, traditional calls, chants and proverbs, and a didactic element.

Nokulunga is seized by a group of young men when she goes to fetch water together with her friends at the river and is carried off whilst the men chant a wedding song and acquiescent neighbours watch. Feeling betrayed not only by her community but also by her own parents, whose concern is for the 13 head of cattle and the horse that they will receive as lobola for her, Nokulunga fiercely resists her young husband-to-be, Xolani, when he tries to take her by force. Mhlophe's story offers a more complex gendered perspective than Kaschula's, however, in that it shows how young men are also subjected to patriarchal discourses. Xolani is ridiculed by his father, elder brother and uncles as 
a 'little boy' (Mhlope 2002:68) who has failed to perform as a man, so that the family have to devise a way of assisting him. The next night a number of men of her husband's age come into the hut, strip Nokulunga and hold her down on the bed. She sees how reluctantly Xolani undresses and she registers his youthful distress: 'He stood there with eyes wide open, as if he were in the country of dreams, and he looked like a lost little boy. Was this the man she should respect as a husband?' (p. 70). The men then place Xolani on top of her. Mhlophe's (2002) narrative graphically exposes the brutal act of collective violence that is at the heart of this so-called cultural tradition:

Each of her legs was pulled apart by a man. Other men held her arms. Xolani's friends were cheering and clapping their hands while he jumped high, now enjoying the rape. One man joked that he had had enough of holding the leg and wanted a share of his work. Things were said too about her bloody thighs, amidst roars of laughter, before she fainted. (Mhlope 2002:70)

The rape is the signal for the community to prepare for the wedding. The corruption of indigenous cultural values through the debased practice of ukuthwala and its sanction by the community are narratively enacted in the final pages of the story as traditional songs are incorporated into the tale of violation. After the accomplice rapists have chorused triumphantly about the girl they have possessed that "The bride is ours/ The bride is ours/ Mother will never go to sleep/ without food/ without food'" (Mhlope 2002:70), young girls sing Xhosa songs and dance in anticipation of the wedding celebrations, ululating " Lililili ... lili ... lili ... liiiiiiii!/ To give birth is to stretch your bones! What do you say, woman who never gave birth?"' (p. 71). Nokulunga is reluctantly instructed in the wisdoms of womanhood and when she later gives birth to a baby boy, she resigns herself to Xolani being her 'lifetime partner, and that there was nothing she could do about it' (p. 72). The complex truth about social and individual acceptance of the unacceptable is reiterated in the refrain of the simple, last sentence: 'There was truly nothing to be done' (p. 72).

\section{Circumcision and manhood: Thando Mgqolozana's A man who is not a man}

In current debates around male circumcision and female excision, it is generally agreed that circumcision is a rite of separation, which removes the individual from one group - the common mass of humanity, that is the uncircumcised - and incorporates him into another, defined group - the circumcised. Chantal Zabus (2008a:xx) explains that, as opposed to neonatal circumcision, circumcision undergone at puberty or in adolescence is a 'rite of passage' and quintessentially African. Its aim is 'to demarcate sex affiliation in the flesh' (xx); it 'functions as a symbol of patrilinearity' (xxii); for a boy it signifies entry into manhood and initiation into 'holy things linked with the masculine' (xxiii). ${ }^{5}$ It is a symbol of his identity as a man.

5.See Sami A. Aldeeb Abu-Sahlieh (2008), "Male cirumcision/female circumcision Is there any difference?' for a comprehensive overview of circumcision practices.
Thando Mgqolozana's (2009) pseudo-autobiographical novel, A man who is not a man, illustrates fundamental truths about all self-writing or life-writing. The first is that self and story are complementary and mutually constitutive in the process of identity formation; in the words of Paul John Eakin (1999):

When it comes to autobiography, narrative and identity are so intimately linked that each constantly and properly gravitates into the conceptual field of the other. Thus, narrative is not merely a literary form but a mode of phenomenological and cognitive self-experience, while self - the self of autobiographical discourse - does not necessarily precede its constitution in narrative. (p. 100)

Or, as Eakin (1999:137) further formulates it, narrative is 'an integral part of a primary mode of identity experience, that of the extended self, the self in time'. Mgqolozana's novel deals more directly with its subject of circumcision and identity than does Jacques Derrida's (1993) Circumfession, his 'circumfictions' about his own circumcision (see Zabus 2008b:102). Mgqolozana quotes E.L. Doctorow as his epigraph: 'There's no longer any such thing as fiction and non-fiction, there's only narrative', and his protagonist, Lumkile, begins his first-person account of the trauma of his failed circumcision with the words: "This story is about how I came to have an abnormal penis. So there you have it: my genital organ is not the normal type. By that I mean it hasn't got the distinctive lollipop shape with knobbly head that most men boast of' (Mgqolozana 2009:1).

The second truth about self-writing or life-writing (still following Eakin) is that identities are formed and narrated through social and discursive transaction:

even though ... there is a legitimate sense in which autobiographies testify to the individual's experience of selfhood, that testimony is necessarily mediated by available cultural models of identity and the discourses in which they are expressed. (Eakin 1999:44)

Lumkile's coming-of-age story tells of how he acquires an adult male identity in the interspace between two conflicting cultural discourses - what Leon de Kock calls a cultural seam. The seam is De Kock's (2001:272) metaphor which corresponds to Hall's theory of cultural suture - for understanding the ways in which identities formed in South Africa across 'schisms, barriers, and misperceptions' have been represented in writing. The seam, De Kock (2001) says, is a 'site of a joining together that also bears the mark of the suture' (p. 276). The seam, he suggests, is:

not only the site of difference ... but it necessarily foregrounds the representational suture, the attempt to close the gap and to bring the incommensurate into alignment by the substitution, in the place of difference, of a myth, a motif, a figure, or a trope. (De Kock 2001:276)

The seam, he argues, is therefore the site of both difference and convergence; it is the place where 'the representational "translation" of difference' happens, the place 'where difference and sameness are hitched together - where they are brought into self-awareness, denied, or displaced into third terms' (De Kock 2001:277). Because South Africa has so overwhelmingly been a place of dualisms - the civilized and the savage, settler and indigene, White and Black, oppressed and privileged, rich and poor' (p. 285) - he proposes that 
'perhaps to be a "South African" writer in the full sense requires imaginative inhabitation of the seam as a deep symbolic structure' (p. 284).

Mgqolozana's 'poetics of the seam' can be seen in Lumkile's narrative language, which is metonymic of the cultural suturing in the novel: township slang expressions are stitched together with more formal isiXhosa words and phrases into the colloquial idiom of a streetwise adolescent. In Cape Town, where he lived with his reprobate father, the 18-year-old Lumkile had fallen into a life of delinquency, drugs and petty crime - a typical township life, he says: 'instantaneous, abrupt, fast and in constant climax ... the crux of the young Black story in South Africa' (Mgqolozana 2009:37). When his mother, a teacher, comes to fetch him back to her rural village of Ngojini in the Eastern Cape to complete his final year of high school, he is initially bored by its backwardness, but soon fashions a new self-image. He retains his snappy urban personal style, but also appreciates the traditional values of his grandfather's house; as he is now able to say about himself: "These days, I liked the guy in the mirror - and the one reflected in people's corneas when they looked at me' (p. 36).

As stated earlier, autobiographical testimonies are mediated by cultural discourses: 'In forming our sustaining sense of self, we draw on models of identity provided by the cultures we inhabit' (Eakin 1999:46). Lumkile's goals are, on the one hand, to matriculate from high school at the end of the year and go to university and, on the other, to undergo the traditional circumcision which his elders have decreed for him. These he recognises as his twin modern and traditional routes to manhood - in the words of a schoolmate who has himself undergone traditional circumcision:

The circumcision process is a physical and tangible manifestation of what manhood is really all about. It teaches you how to endure, how to manoeuvre your way through and out of the difficult situations that life presents to you. It trains you in the lessons of patience, for it is something that cannot be rushed through but can only be completed step by step. (Mgqolozana 2009:65)

What is most important about the initiation rite is the need to 'articulate your manhood' (Mgqolozana 2009:65, emphasis added). Or, as Kathryn Stinson (2011) explains:

Initiation is seen as the 'formal incorporation of males into Xhosa religious life and tribal life', and before circumcision a male cannot marry or start a family, inherit possessions, nor officiate in ritual ceremonies. (Stinson 2011:3)

The uncircumcised man is condemned to eternal boyhood, shunned socially, called names, and generally victimised. Moreover, Mgqolozana's narrative makes clear that the 'zigzag scars of sutures' (2009:155) are regarded with contempt as the sign of a hospital circumcision, which 'is not considered to be a real circumcision' (p. 154).

Lumkile's account of his coming of age at the seam between two conflicting cultural traditions also combines two kinds of autobiographical narrative. More generally, the story of his circumcision provides an auto-ethnographic account of the traditional Xhosa ritual, as well as of its present-day corruption. Some 10000 males between the ages of 15 and 25 are circumcised annually in the Eastern Cape in sacred and secret ceremonies, the details of which are especially taboo for women and uncircumcised boys. ${ }^{6}$ Often, under the auspices of a traditional healer, a recognised traditional surgeon (incgibi) and a guardian (inkhankatha), or attendant nurse, are appointed, a goat is ritually slaughtered at each initiate's homestead the day before the circumcision and, early in the morning, a circumcision lodge or hut is erected by the village men. The initiates (abakhwetha) are stripped of their clothing, symbolically marking the break with boyhood, and given blankets to be worn throughout the weeks of the ritual. The circumcision is carried out by the surgeon with a spear and each boy is expected to suffer the pain of the operation stoically, calling out 'Ndiyindoda' ['I am a man'] at the time of being cut. For a week after the circumcision, drinking of liquid and eating of soft foods are forbidden. The lodge guardian visits the hut regularly to dress the circumcision wounds with traditional herbs and medicines. As the wounds begin to heal, the initiates remain secluded and, dressed only in their blankets, paint their bodies with white clay, sing traditional songs and perform traditional dances as part of their induction into their culture. Once the wounds are healed, the initiates are reintegrated into their community; their heads are shaved and they are chased to a nearby river to wash the clay - and symbolically their boyhood - from their bodies, after which they are anointed with a special ointment. In a 'coming-out ritual', they give up their old blankets and are given new ones, and the initiation hut and its contents are burnt. They then rejoin the community, are given new clothes, and their faces painted with red ochre as a mark of their status as a 'new man'. Gifts are then presented to the initiates and they are instructed to respect their elders, parents and chiefs.

Circumcision in the Eastern Cape has turned into a public health crisis. Negligent parents, unscrupulous and inexperienced fly-by-night surgeons, and ignorant and careless attendants have resulted in young initiates suffering from dehydration, septicaemia and gangrene, and landing up in hospital in their hundreds every year. In July 2011, the Eastern Cape Health Department reported that, over the past four years, 230 initiates have died following botched circumcisions and that, in addition, 150 young men had to have their penises amputated as a result of complications following the procedure (see The Mercury 01 August 2011:3). ${ }^{7}$ The Government has been forced to intervene through the Application of Health Standards in Traditional Circumcision Act (Eastern Cape) (Act No. 6 of 2001) (Eastern Cape Provincial Legislature 2001) and the National Health Act (Act No. 61 of 2003) (Republic of South Africa 2003), which regulate the holding of circumcision schools and registration of traditional surgeons.

6.I draw largely here on the World Health Organization Reproductive Health and Research Department (2008) report, Male circumcision policy, practices and services in the Eastern Cape province of South Africa: Case study.

7.See also Ortrun Meissner and David L. Buso's (2007) analysis of the crisis around traditional male circumcision in the Eastern Cape. 
More specifically, Lumkile's story of his circumcision is also a personal account of how he becomes one of these public health statistics. His drunken grandfather, whose duty it is to host and supervise the circumcision ceremony, abandons him to his uncle, who, in turn, instead of fulfilling his aftercare responsibilities as Lumkile's attendant, deserts him to go off sheep-shearing. After his circumcision, Lumkile is left to his own devices in the corrugated iron lean-to that he has had to erect for himself with the help of two distant relatives and with only his frightened 10-year-old brother to bring him hard maize kernels to eat during the first week of privation without water or sleep. Although he at first endures the pain from his wound that 'is hard to describe' (Mgqolozana 2009:87) as a necessary lesson in manhood, the agony becomes unbearable as his penis turns gangrenous and begins to rot away. He is caught in a conflict between realising that he needs urgent medical attention and the taboo that 'what happens at the mountain stays at the mountain' (p. 92), and that to seek outside help 'would be to betray the culture and flout the customs of [his] people' (p. 92). Dehydrated and dizzy from lack of sleep, he nevertheless perseveres: he smears his body with white clay, to resemble a goat, and speaks in the tones of a baboon because 'in the code language of the mountain, an initiate is an animal ...' (p. 104).

After three days he is eventually delivered by his angry and humiliated grandfather to the hospital, where he joins other silent initiates who are so traumatised that they keep their heads covered under the blankets. He has further to endure the scorn of a nurse who, he says, regards them all as cowards who have 'chickened out' (Mgqolozana 2009:122) and ended up in hospital - 'manhood rejects', destined to have a 'subhuman status' in society. Feeling emotionally violated and suicidal, and craving only gentleness and understanding, Lumkile realises that instead of his having betrayed his culture through wrongdoing, it is 'men like his grandfather who, in fact, betrayed their own culture' (p. 130) by abdicating their custodial responsibility. In Lumkile's words:

It was because of the sins of our fathers that we initiates ended up with permanent trauma, robbed of the respect of our community and ostracised by our society as men who weren't real men. (Mgqolozana 2009:130)

Determined to complete his journey to manhood, Lumkile sneaks back to his initiation hut when he is discharged, fearful and angry. When on the day of his coming-out he is met by a crowd of village men, he feels that he is an outcast in the community, 'an object of scorn and scrutiny' (Mgqolozana 2009:150). But convinced that the failure is not only his, but also the culture's, and reassured by the sympathetic Ta-Rain's advice, "'Remember this ... from today, you are a man in your own right"' (p. 151), he completes the final stage of ritually washing away his boyhood in the river and participates in the ceremonial singing and dancing, as well as the night vigil in the house of the lamp, where his sexual socialisation takes place. The next morning he not only receives instruction in the protocols of manhood but is also given the news of his matriculation pass. His initiation into manhood is complete when one of the elders, Oom Dan, conveys his regret for what has befallen Lumkile by presenting him with his own knobkerrie, which, the young man realises, symbolises 'the privilege to handle the manhood of a grown man' (p. 171).

The self, Eakin (1999:43) reminds us, 'is defined by - and lives in terms of - its relations with others'. Because the claim to an autonomous self depends upon its being recognised by others, he says, 'identity is necessarily relational' (1999:52). In an epilogue, Lumkile explains the psychological and emotional damage caused by his having 'a deformed penis' (Mgqolozana 2009:178), being 'a statistic', and being 'a flawed man in the eyes of some'. Throughout his subsequent university career and work as a researcher, the subject of what happened to him is never mentioned at home; his relationships with women end before being consummated; nor does he allow men, especially Xhosa men, to come too close for fear of the subject of manhood being raised. Because Xhosas would regard him as 'a bogus man' (2009:181), he is more comfortable with men of other tribes and races than his own, and leads a split life. He says in conclusion that, strangely enough, his supposedly 'failed' circumcision has made him 'feel more like a real man, not less' (2009:182). 'If manhood is about enduring pain in its literal and figurative sense', then he has more than earned it. His experience has allowed him 'a deeper understanding of what manhood is really about' (2009:183). The lesson that he has learnt from his initiation is that 'just as in seclusion a man must heal himself without dependency on others, so the same is true of the journey of life'. For Lumkile, the true articulation of his manhood is to break the silence seven years later and write his story of survival and self-acceptance.

\section{Conclusion}

Madumo, Sweetness, Nokulunga and Lumkile are young biographical and fictional South African subjects who have all come of age and forged a modern identity across a divide between, and also within, cultures. They identify themselves as westernised individuals; on the other hand, however, they also subscribe to traditional African values, whilst recognising how they themselves have been damaged by cultural malpractices. Self-reflexive critical and imaginative engagement by young people with the cultures that have formed - and deformed - them is, I suggest, a mark of the true coming-of-age of postcolonial and post-apartheid writing.

\section{Acknowledgements Competing interests}

The author declares that he has no financial or personal relationships which may have inappropriately influenced him in writing this article.

\section{References}

Abu-Salieh, S.A.A., 2008, 'Male circumcision/female circumcision: Is there any difference?', in C. Zabus (ed.), Fearful symmetries: Essays and testimonies around excision and circumcision, Matatu 37, pp. 3-49, Rodopi, Amsterdam.

Ashforth, A., 2000, Madumo: A man bewitched, University of Chicago Press, Chicago. Bhabha, H.K., 1994, The location of culture, Routledge, London. 
Birrell, I., 2011, 'Royal mess worsens: Africa's last absolute monarch, King Mswati III, faces a revolt as his subjects demand a better life', Sunday Tribune 13 November, p. 15.

Carton, B., Laband, J. \& Sithole, J. (eds.), 2008, Zulu identities: Being Zulu, past and present, University of KwaZulu-Natal Press, Pietermaritzburg.

'Circumcision deaths', The Mercury, 01 August 2011, p. 3.

Clingman, S., 2009, The grammar of identity: Transnational fiction and the nature of the boundary, Oxford University Press, Oxford.

Constitution of the Republic of South Africa, 1996, viewed 09 August 2012, from http://www.info.gov.za/documents/constitution/1996/index.htm.

'Muti house of horror', Daily News, 04 February 2011, p. 3.

De Kock, L., 2001, 'South Africa in the global imaginary: An introduction', Poetics Today 22(2), Summer, 263-298.

Derrida, J. [1991] 1993, Circumfession, transl. G. Bennington, University of Chicago Press, Chicago.

Eakin, P.J., 1999, How our lives become stories: Making selves, Cornell University Press, Ithaca.

Eastern Cape Provincial Legislature, 2001, Application of Health Standards in Traditional Circumcision Act (Eastern Cape) (Act No. 6 of 2001), viewed 09 August 2012, from http://www.legalb.co.za/SAPROV/EC_Leg_Orig.htm

Gasa, N., 2010, Nomboniso Gasa: We need to shine the light in the dark corners of our cultures, Rural Women's Movement of South Africa, 11 August, viewed 18 August 2011, from http://rwmsa.org/2010/08/11/nomboniso-gasa/

Hall, S., 1990, 'Cultural identity and diaspora', in J. Rutherford (ed.), Identity, community, culture, difference, pp. 222-237, Lawrence and Wishart, London.

Hammond-Tooke, W.D., 2008, 'Cattle symbolism in Zulu culture', in B. Carton, J. Laband \& J. Sithole (eds.), Zulu identities: Being Zulu, past and present, pp. 62-68, University of KwaZulu-Natal Press, Pietermaritzburg.

Huisamen, T., 2010, 'Tim Huisamen: Six teaspoons of sweetness: The ukuthwala custom (Amaxhosa legal marriage 'abduction') in fact and fiction', presented by B. Nosilela, T. Huisamen \& R. Kaschula at the University of Fort Hare, ECSECC and Harold Wolpe Dialogue, Claremont, 14 October, Harold Wolpe Memorial Trust, Cape Town, p. 20-23.

Kaschula, R.H., 2011, 'Six teaspoons of sweetness', in South African PEN \& J.M Coetzee (eds.), African pens 2011: New writing from southern Africa, pp. 209-221, Johannesburg.

Lambert, M., 2008, 'Nomkhubulwane: Reinventing a Zulu goddess', in B. Carton, J. Laband \& J. Sithole (eds.), Zulu identities: Being Zulu, past and present, pp. 545553, University of KwaZulu-Natal Press, Pietermaritzburg.
5ival

Magwaza, T., 2008, '"So that I will be a marriageable girl"': umemulo in contemporary Zulu society', in B. Carton, J. Laband \& J. Sithole (eds.), Zulu identities: Being Zulu, past and present, pp. 482-496, University of KwaZulu-Natal Press, Zulu, past and
Pietermaritzburg.

Marcus, T., 2008, 'Virginity testing: A backward-looking response to sexual regulation in the HIV/AIDS crisis', in B. Carton, J. Laband \& J. Sithole (eds.), Zulu identities: Being Zulu, past and present, pp. 536-544, University of KwaZulu-Natal Press, Pietermaritzburg.

Meissner, O. \& Buso, D.L., 2007, 'Traditional male circumcision in the Eastern Cape Scourge or blessing?', South African Medical Journal 97(5) May, 371-373.

Mgoduka, Z., 2011, uQongqothwane (The musical), 19 August, Port Elizabeth Opera House.

Mgqolozana, T., 2009, A man who is not a man, University of KwaZulu-Natal Press, Pietermaritzburg.

Mhlophe, G., 2002, 'Nokulunga's wedding', in G. Mhlophe, Love child, pp. 64-72, University of KwaZulu-Natal Press, Pietermaritzburg.

Minnaar, A., 2003, 'Legislative and legal challenges to combating witch purging and muti murder in South Africa', in J. Hund (ed.), Witchcraft violence and the law in South Africa, pp. 33-92, Protea Book House, Pretoria.

'Mutilated body indicates muti killing', The Mercury, 02 August 2011, p. 4
National Prosecuting Authority, 2011, 'Waging war against criminal element of ukuthwala practice', Daily News 29 August, pp. 6-7.

Nosilela, B., 2010, 'Buselwa Nosilela: Six teaspoons of sweetness: the ukuthwala custom (Amaxhosa legal marriage 'abduction') in fact and fiction', presented by B. Nosilela, T. Huisamen \& R. Kaschula at the University of Fort Hare, ECSECC and Harold Wolpe Dialogue, Claremont, 14 October, Harold Wolpe Memorial Trust, Cape Town, pp. 2-4.

Nuttall, S., 2009, Entanglement: Literary and cultural reflections on post-apartheid, Wits University Press, Johannesburg.

Osaaji, M.G., 2009, 'Will they survive the margins? Endangered languages and oral traditions in Kenya', in G.N. Devy, G.V. Davis \& K.K. Chakravarty (eds.), Indigeneity: Culture and representation, pp. 121-132, Orient BlackSwan, New Delhi.

Republic of South Africa, 2003, National Health Act (Act No. 61 of 2003), viewed 09 August 2012, from http://www.acts.co.za/national_health/national_health_act_ 2004.htm

Republic of South Africa, 2005, Children's Act (Act No. 38 of 2005), viewed 09 August 2012, from http://www.justice.gov.za/legislation/acts/2005-038\%20childrensact.pdf

Republic of South Africa, 2007, Sexual Offences and Related Matters Act (Act No. 32 of 2007), viewed 09 August 2012, from http://www.justice.gov.za/docs/ 32 of 2007), viewed 09 August 2012, from http:
InfoSheets/2008\%2002\%20SXOactInsert_web.pdf

Republic of South Africa, 2008, Traditional Health Practitioners Act (Act No. 22 of 2007), Government Gazette 511(30660), Government printers, Pretoria, viewed 09 August 2012, from http://www.info.gov.za/view/DownloadFileAction?id=77788

Republic of South Africa, 2009, National House of Traditional Leaders Act (Act No. 22 of 2009), viewed 09 August 2012, from http://www.polity.org.za/article/nationalhouse-of-traditional-leaders-act-no-22-of-2009-2010-02-10

Said, E.W., 1994, Culture and imperialism, Vintage, London.

South African Broadcasting Corporation, 2011, Special Assignment: Ukuthwala, aired 21 February, 21:00, SABC 3, executive producer: Johann Abrahams.

South African Broadcasting Corporation and Department of Constitutional Development (co-producers), 2011, Final Verdict - Episode 08 (Ukuthwala), aired Development (co-prod
30 July, 11:30, SABC 2.

Statistics South Africa, 2011, 'Statistical Release P0302', viewed 09 August 2012, from http://www.statssa.gov.za/publications/P0302/P03022011.pdf

Stilz, G., 2009, 'Friends, indigenes and others: A German interjection', in G.N. Devy, G.V. Davis \& K.K. Chakravarty (eds.), Indigeneity: Culture and representation, pp. 12-28, Orient BlackSwan, New Delhi.

Stinson, K., 2011, Male circumcision in South Africa: How does it relate to public health?, viewed 26 September 2011, from http://www.africanvoices.co.za/ culture/circumcision.htm

'Three held after man killed for body parts', Sunday Tribune, 06 February 2011, p. 4.

'Relatives cheer as muti killer is jailed', The Mercury, 29 November 2011, p. 5.

Tshabalala-Msimang, M., 2009, 'Speech by Minister in the Presidency Dr Manto Tshabalala-Msimang at the seminar on harmful traditional practices, $30 \mathrm{March}^{\prime}$ South African Government Information, viewed 18 August 2011, from http:// South African Government Information, viewed 18 Augu
www.info.gov.za/speeches/2009/09033016451003.htm

World Aids Campaign, 2011, 'Ukuthwala - stolen innocence'. Documentary film on gender-based violence in Eastern Cape of South Africa.

World Health Organization Reproductive Health and Research Department, 2008, Male circumcision policy, practices and services in the Eastern Cape province of South Africa: case study, viewed 26 September 2011, from http://www. malecircumcision.org/publications/documents/South_Africa_MC_case_study_ May_2008_002.pdf

Zabus, C., 2008a, 'Introduction: Why not the earlobe?', in C. Zabus (ed.), Fearful symmetries: Essays and testimonies around excision and circumcision, Matatu 37 pp. xi-xxxii, Rodopi, Amsterdam.

Zabus, C., 2008b, "'Beyond circumspection": African, Jewish, and Muslim autobiographies around circumcision', in C. Zabus (ed.), Fearful symmetries: Essays and testimonies around excision and circumcision, Matatu 37, pp. 99-128, Rodopi, Amsterdam. 